\title{
Four-year Measurements of Wet Mercury Deposition at a Tropical Mountain Site in Central Taiwan
}

\author{
Ly Sy Phu Nguyen, Guey-Rong Sheu* \\ Department of Atmospheric Sciences, National Central University, Taoyuan 32001, Taiwan
}

\begin{abstract}
Rainwater samples were collected between 2010 and 2013 at Lulin Atmospheric Background Station (LABS) to study the distribution and characteristics of wet mercury $(\mathrm{Hg})$ deposition, and possible driving mechanisms. Sample $\mathrm{Hg}$ concentrations ranged from 0.8 to $35.1 \mathrm{ng} \mathrm{L}^{-1}$ with an overall volume-weighted mean (VWM) concentration of $9.2 \mathrm{ng} \mathrm{L}^{-1}$. Annual wet $\mathrm{Hg}$ deposition fluxes ranged between 24.4 and $48.9 \mu \mathrm{g} \mathrm{m}^{-2}$ with a mean value of $32.3 \mu \mathrm{g} \mathrm{m} \mathrm{m}^{-2}$. This mean annual wet flux was about 1.5-6.0 times the values measured at 15 sites in the U.S. and 4-16 times the values reported from mountain and high-elevation sites in China. Both rainwater $\mathrm{Hg}$ concentration and rainfall amount contributed to this geographical difference, but rainfall amount played a more important role. This indicated that tropical mountains in East and Southeast Asia, especially the windward maritime slopes with abundant rainfall, could be hot spots of wet $\mathrm{Hg}$ deposition. Wet $\mathrm{Hg}$ deposition flux was high in summer because of elevated rainwater $\mathrm{Hg}$ concentrations and high rainfall. The seasonal pattern of rainwater $\mathrm{Hg}$ concentrations was different from that of the East Asian air pollutant export, indicating other factors, e.g., rainfall type, were also influencing rainwater $\mathrm{Hg}$ concentrations. A clear difference in seasonal frequency distribution of rainfall types was observed, with rain events associated with the Pacific high pressure type (PH) occurring more frequently in summer months. PH rainfall type had the highest VWM Hg concentration $\left(13.5 \mathrm{ng} \mathrm{L}^{-1}\right), 2.3-$ $6.2 \mathrm{ng} \mathrm{L}^{-1}$ greater than those of the other rainfall types. Because of intense surface heating under summer PH conditions, precipitation systems usually form locally due to strong convection, resulting in afternoon shower. Therefore, the elevated rainwater $\mathrm{Hg}$ levels in summer at LABS were likely due to the scavenging of free tropospheric gaseous oxidized $\mathrm{Hg}(\mathrm{GOM})$ by deep convection.
\end{abstract}

Keywords: East Asia; Rainwater; Rainfall type; Scavenging.

\section{INTRODUCTION}

Mercury $(\mathrm{Hg})$ is a persistent and bioaccumulative toxicant of global concern with widespread anthropogenic emission sources (UNEP, 2013). The most important source of inorganic $\mathrm{Hg}$ to many terrestrial and aquatic ecosystems is deposition from the atmosphere, especially in remote areas and the open oceans where local anthropogenic $\mathrm{Hg}$ emission sources are scarce (Mason and Sheu, 2002; Keeler et al., 2005; Sunderland et al., 2007; Mason, 2013). Both wet and dry deposition processes are important (Zhang et al., 2017). However, compared to dry deposition, sampling and quantification of wet deposition are more accurate and hence more popular worldwide (Cole et al., 2014; Weiss-Penzias et al., 2016; Wright et al., 2016; Sprovieri et al., 2017).

\footnotetext{
* Corresponding author.

Tel.: +886-3-4227151 ext. 65514

E-mail address: grsheu@atm.ncu.edu.tw
}

Measurements of wet $\mathrm{Hg}$ deposition have been conducted at sites in major continents, such as North America (Civerolo et al., 2014; Prestbo and Gay, 2009), South America (Fostier et al., 2000; Hansen and Gay, 2013), Europe (Fu et al., 2015; Sprovieri et al., 2017), South Africa (Brunke et al., 2016), and East Asia (Sakata and Marumoto, 2005; Seo et al., 2012; Sheu and Lin, 2013; Fu et al., 2016; Nguyen et al., 2016). For instance, wet $\mathrm{Hg}$ deposition fluxes ranged from 3.0 to $25.0 \mu \mathrm{g} \mathrm{m}^{-2} \mathrm{yr}^{-1}$ at various Mercury Deposition Network (MDN) sites over the U.S. between 1996 and 2005, and higher wet $\mathrm{Hg}$ fluxes were observed along the Gulf Coast (Prestbo and Gay, 2009). Wet Hg deposition fluxes of 5.8-17.7 $\mu \mathrm{g} \mathrm{m}^{-2} \mathrm{yr}^{-1}$ have been reported from 10 sites across Japan (Sakata and Marumoto, 2005). Fu et al. (2016) reported annual wet-only $\mathrm{Hg}$ deposition fluxes ranging from 1.8 to 7.0 and from 13.4 to $56.6 \mu \mathrm{g} \mathrm{m}^{-2}$ for remote and urban sites in China, respectively. Sheu and Lin (2013) reported an annual wet $\mathrm{Hg}$ deposition flux of $10.2 \mu \mathrm{g} \mathrm{m}^{-2}$ to Pengjiayu, a remote islet in the Northwest Pacific Ocean. However, most of these measurements were conducted in the temperate region. Measurements conducted in the tropical region are not as common. 
Measurement and model studies suggested that the tropical areas could be hot spots for wet $\mathrm{Hg}$ deposition because of the high rainfall (Hansen and Gay, 2013; Shanley et al., 2015; Horowitz et al., 2017). For instance, Shanley et al. (2015) measured high wet $\mathrm{Hg}$ deposition of $27.9 \mu \mathrm{g} \mathrm{m}^{-2} \mathrm{yr}^{-1}$ at a tropical wet forest site in Puerto Rico, which was driven in part by high rainfall $\left(2855 \mathrm{~mm} \mathrm{yr}^{-1}\right)$. This suggested that the other tropical areas, where high rainfall occurs, maybe hot spots for wet $\mathrm{Hg}$ deposition as well (Shanley et al., 2015). The average rainfall over East and Southeast Asia tropical climate zone is approximately $2000 \mathrm{~mm} \mathrm{yr}^{-1}$ and could be greater than $3000 \mathrm{~mm} \mathrm{yr}^{-1}$ on windward maritime slopes (Celâl Şengör et al., 2019). However, wet $\mathrm{Hg}$ deposition measurements are scarce in the tropical region of East and Southeast Asia (Sprovieri et al., 2017; UN Environment, 2019). Therefore, measurement data of $\mathrm{Hg}$ wet deposition to the tropical region of East and Southeast Asia are crucial to improve our understanding of the regional and global $\mathrm{Hg}$ cycles (Horowitz et al., 2017; Sprovieri et al., 2017).

Wet $\mathrm{Hg}$ deposition could be affected by several factors, including rain depth, atmospheric chemistry and transport, distribution of emission sources, and rainfall types (Gratz et al., 2009; Holmes et al., 2016; Kaulfus et al., 2017; Mao et al., 2017a, b). Meteorological conditions, such as rain depth and rainfall types, have been demonstrated to play important roles in controlling wet $\mathrm{Hg}$ deposition (Gratz et al., 2009; Sheu and Lin, 2013; Shanley et al., 2015; Mao et al., 2016). Annual and interannual patterns of wet $\mathrm{Hg}$ deposition were found to be determined by rainfall amount (Gratz et al., 2009; Mao et al., 2016). Besides, the occurrence of deep convection has been suggested to contribute to the elevated rainwater $\mathrm{Hg}$ concentration in summer (Sheu and Lin, 2013; Shanley et al., 2015). Recent studies also indicated that thunderstorm, a rainfall type due to strong convection, can increase rainwater $\mathrm{Hg}$ concentration as well as wet $\mathrm{Hg}$ deposition over the U.S. (Holmes et al., 2016; Kaulfus et al., 2017). For example, Holmes et al. (2016) found thunderstorm can increase rainwater $\mathrm{Hg}$ concentration by $50 \%$ as compared to other rainfall types. These were attributed to scavenging of upper-altitude GOM by deep convection (Selin and Jacob, 2008). Results of these studies indicated the connection between wet $\mathrm{Hg}$ deposition and rainfall type.

The relationship between anthropogenic $\mathrm{Hg}$ emissions and wet $\mathrm{Hg}$ deposition has been documented by numerous studies (e.g., Fu et al., 2016; Mao et al., 2016; WeissPenzias et al., 2016; Sprovieri et al., 2017). Asia is the greatest contributor of anthropogenic $\mathrm{Hg}$ to the atmosphere (UNEP, 2013; Zhang et al., 2016b) and the exports of East and Southeast Asia $\mathrm{Hg}$ emissions have been identified in the downwind regions (Friedli et al., 2004; Chand et al., 2008; Sheu et al., 2010; Sheu and Lin, 2011; Sheu et al., 2013; Jen et al., 2014; Chen et al., 2016; Nguyen et al., 2019; Sheu et al., 2019). In addition, various modeling studies indicated that $\mathrm{Hg}$ emissions from East Asia significantly contribute to $\mathrm{Hg}$ deposition over the downwind regions (e.g., Lin et al., 2010; Chen et al., 2014; Chen et al., 2018). Therefore, atmospheric $\mathrm{Hg}$ deposition studies conducted in the downwind regions of East Asia are valuable for verifying the modeling results and thus contributing to improve our understanding in atmospheric $\mathrm{Hg}$ cycling.

Taiwan is located between the East and Southeast Asia continent and the west Pacific Ocean (Fig. 1). In this region, southwest monsoon prevails in summer, which brings a large amount of moisture, whereas northeast monsoon prevails between late fall and spring (Sheu et al., 2010; Sheu and Lin, 2011; Lin et al., 2013). In this study, we reported the four-year (2010-2013) measurements of wet

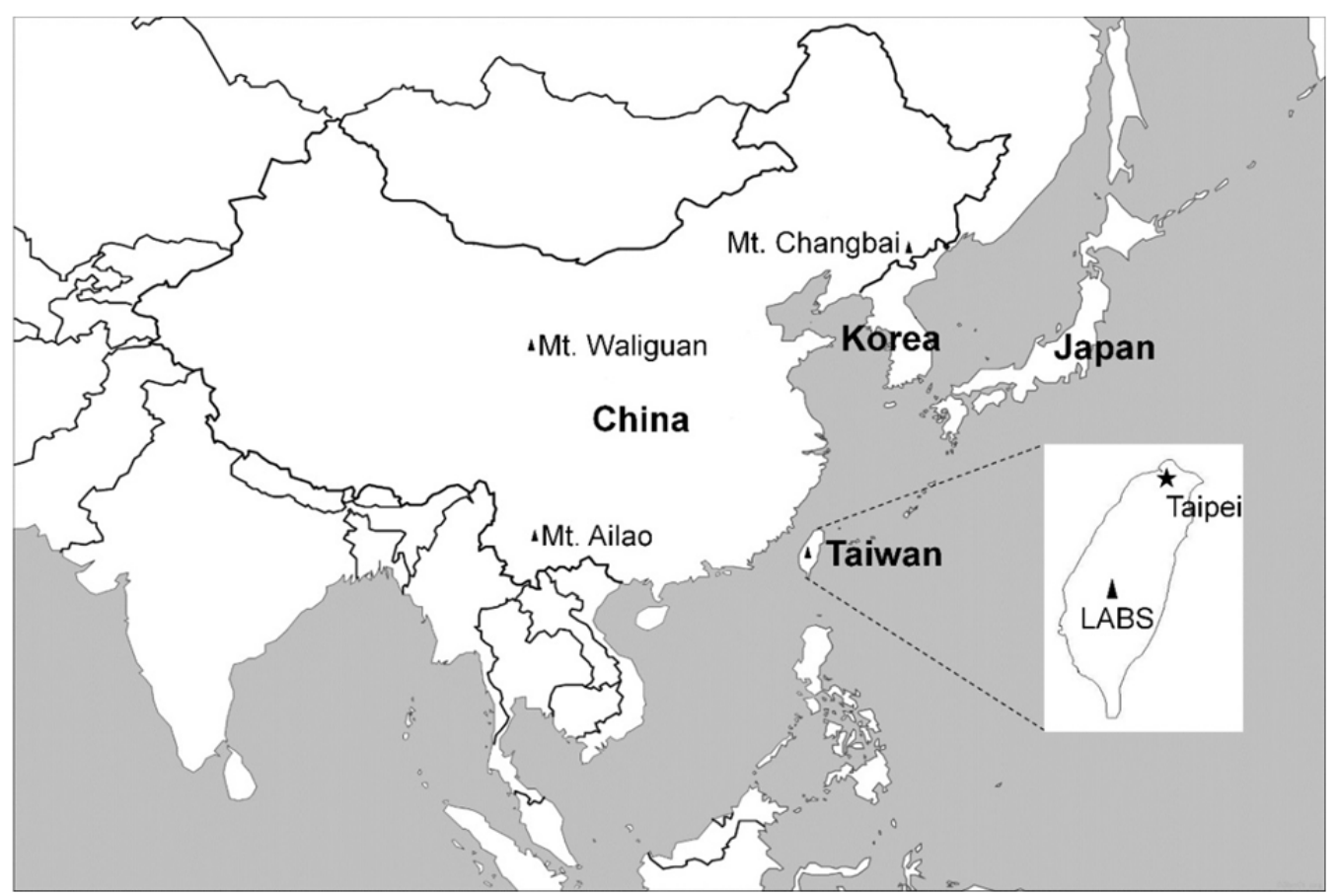

Fig. 1. Location of Taiwan and Lulin Atmospheric Background Station (LABS). 
mercury deposition at the Lulin Atmospheric Background Station (LABS), a tropical mountain site in central Taiwan. The primary objective of this study is to characterize the wet $\mathrm{Hg}$ deposition to a tropical mountain site with high rainfall. The seasonal pattern of wet $\mathrm{Hg}$ deposition and the association of wet $\mathrm{Hg}$ deposition with rainfall type are also discussed, and possible driving mechanisms are discussed. Results of this research also contribute to an improved understanding of the influence of East and Southeast Asian $\mathrm{Hg}$ emissions to the wet $\mathrm{Hg}$ deposition in the downwind mountain areas.

\section{SITE AND METHODS}

\section{Site Description}

Lulin Atmospheric Background Station (LABS; $23.47^{\circ} \mathrm{N}$ $120.87^{\circ} \mathrm{E}, 2862 \mathrm{~m}$ above sea level) is a two-story building on the summit of Mt. Front Lulin in Yu-Shan National Park in central Taiwan (Fig. 1). LABS was established in late 2005 and its official operation began since April 2006 to study the impact of regional and long-range transported air pollutants on the mountain environment and ecosystems in Taiwan (Sheu et al., 2010). There are no significant anthropogenic emission sources of $\mathrm{Hg}$ at the summit or in the surrounding areas. LABS is unique because its location and altitude can complement the global network of Global Atmospheric Watch (GAW) in the East Asia region where no high-elevation baseline station is available (Sheu et al., 2010). According to the meteorological information collected at LABS from January 2007 to December 2017, the overall mean temperature is $10.5^{\circ} \mathrm{C}$ with the highest mean temperature in July $\left(14.1^{\circ} \mathrm{C}\right)$ and the lowest in January $\left(5.6^{\circ} \mathrm{C}\right)$. The average annual rainfall is $3178 \mathrm{~mm}$, with about $50 \%$ occurring in summer (1582 mm, June-August) because of typhoons and thermal convection induced afternoon showers.

\section{Rainwater Sampling and Hg Analysis}

Collection of rainwater samples at LABS for total $\mathrm{Hg}$ analysis began since 2009 and is still continuing. In this study, the first complete four-year (2010-2013) of data were reported and analyzed for characterizing the wet $\mathrm{Hg}$ deposition at LABS. Weekly rainwater samples were collected using an automated wet-only rain collector and an acid-cleaned sampling apparatus (Landis and Keeler, 1997; Sheu and Lin, 2013). The apparatus comprised of a glass funnel connected to a $1 \mathrm{~L}$ Teflon bottle by a Teflon adaptor. A glass vapor lock was used to prevent $\mathrm{Hg}$ evaporation from rainwater after collection. Bottles, glassware, and adaptors were acid-cleaned, rinsed with deionized water, and then air-dried before use. Samples were retrieved and the sampling apparatus was changed every Tuesday at 9 am. Samples were double-bagged before being shipped back to National Central University (NCU) for $\mathrm{Hg}$ analysis. Total $\mathrm{Hg}$ in unfiltered samples was analyzed by dual gold trap amalgamation and cold vapor atomic fluorescence spectrometry (CVAFS) after $\mathrm{BrCl}$ oxidation, hydroxylamine hydrochloride neutralization, and $\mathrm{SnCl}_{2}$ reduction (U.S. EPA, 2002; Sheu and Lin, 2013). To assure the data quality, various QA/QC procedures were routinely performed, such as duplicate analysis, ongoing precision and recovery, matrix spike, bottle blanks, transport blanks, and field blanks. Results of these QA/QC procedures well met the criteria requested by the US-EPA Method 1631, Revision E (U.S. EPA, 2002). Details of the cleaning procedure, rainwater samples analysis, QA/QC procedures can be found in Sheu and Lin (2013).

Between 2010 and 2013, amounts of annual rainfall ranged between 3173 and $3736 \mathrm{~mm}$, with an average of $3421 \mathrm{~mm}$ (Tables 1 and 2). A total of 150 samples were collected, representing around $98 \%$ of the total rainfall. Missing samples occurred mainly due to system malfunction or very low weekly rainfall, resulting in no or insufficient rainwater amount for $\mathrm{Hg}$ analysis. Summer rainfall (mean $=1703 \mathrm{~mm}$ ) contributed about $50 \%$ of the annual rainfall.

\section{Wet Hg Deposition Flux}

Weekly wet $\mathrm{Hg}$ deposition flux was defined as the product of the sample $\mathrm{Hg}$ concentration and the weekly rain depth. Monthly and yearly wet deposition fluxes were estimated by using monthly/yearly VWM Hg concentration and monthly/yearly cumulative rain depth.

\section{Backward Trajectory Analysis}

Backward trajectories (BWTs) were used to identify the origins and transport paths of air masses arriving at LABS. BWTs were calculated using the Hybrid Single Particle Lagrangian Integrated Trajectory (HYSPLIT) model (Draxler and Rolph, 2013) with meteorological data from the NCEP Global Data Assimilation System. Five-day backward trajectories arriving at $2862 \mathrm{~m}$ above sea level (i.e., LABS altitude) at 8 am local time were computed for each day in 2010-2013.

\section{RESULTS AND DISCUSSION}

\section{Rainwater Hg Concentrations}

Rainwater $\mathrm{Hg}$ concentrations ranged from 0.8 to 35.1 ng L ${ }^{-1}$ ((Table 1)), with an overall VWM concentration of $9.2 \mathrm{ng} \mathrm{L}{ }^{-1}$. There was a weak but statistically significant inverse correlation between the rainwater $\mathrm{Hg}$ concentration and weekly rainfall (Fig. 2; $\mathrm{R}^{2}=0.036, p=0.022$ ), indicating rainwater $\mathrm{Hg}$ concentrations decreases with increasing rainfall. This result is similar to previous studies that also observed a significant inverse correlation between rainfall and rainwater $\mathrm{Hg}$ concentration (Prestbo and Gay, 2009; Seo et al., 2012; Wang et al., 2012; Hansen and Gay, 2013; Sheu and Lin, 2013). This was possibly due to the scavenging of atmospheric oxidized $\mathrm{Hg}$ ( $\mathrm{Hg}(\mathrm{II}))$ to rainwater during the initial period of a rain event and the dilution effect caused by substantial rainfall (Selin and Jacob, 2008; Seo et al., 2012; Sheu and Lin, 2013).

Table 2 summarized the VWM $\mathrm{Hg}$ concentrations in rainwater and wet $\mathrm{Hg}$ fluxes measured at LABS and numerous sites worldwide with different site characteristics. The VWM Hg concentration of LABS (9.2 $\left.\mathrm{ng} \mathrm{L}^{-1}\right)$ was close to the values of various rural and remote sites, such as Puerto Rico (9.8 $\mathrm{ng} \mathrm{L}^{-1}$ ) and Pengjiayu, Taiwan $\left(8.9 \mathrm{ng} \mathrm{L}^{-1}\right)$, 


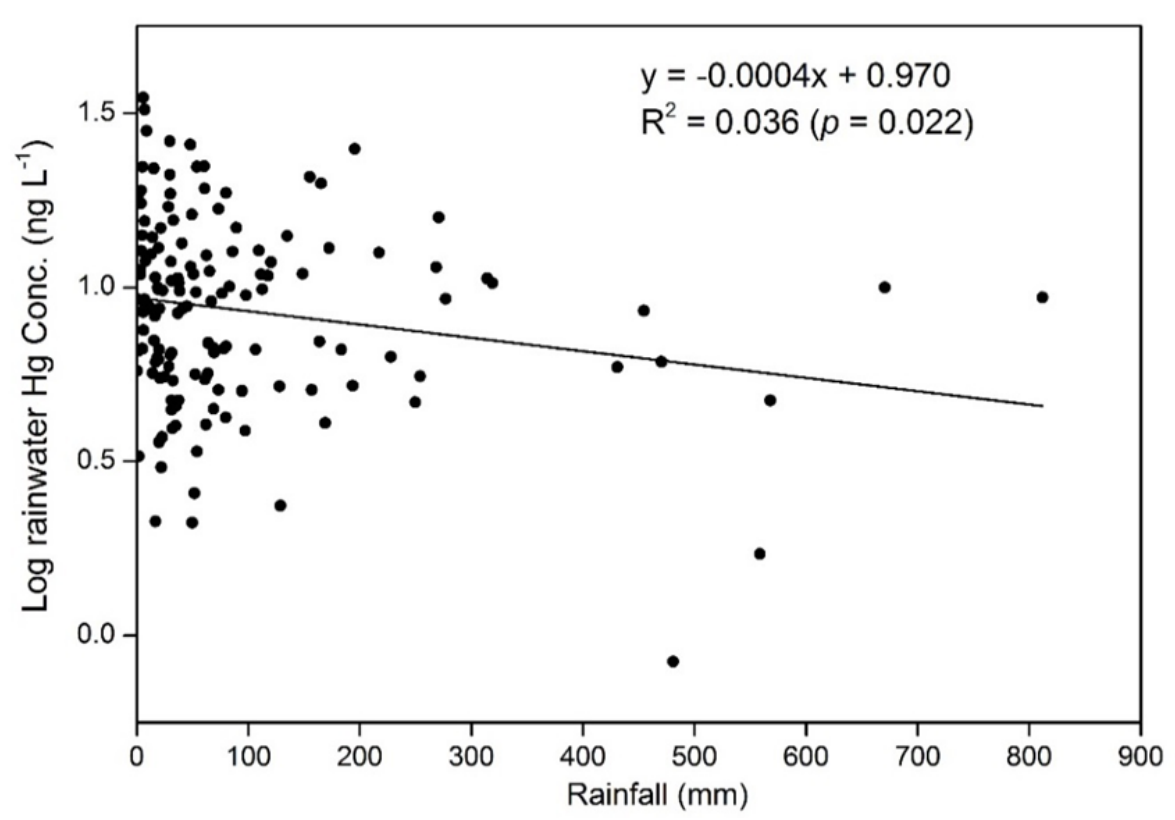

Fig. 2. Relationship between rainwater $\mathrm{Hg}$ concentration and rainfall.

much lower than the urban sites, such as Kathmandu, Nepal (18.3 $\mathrm{ng} \mathrm{L}^{-1}$ ), Seoul, Korea (10.1-16.3 $\mathrm{ng} \mathrm{L}^{-1}$ ), and Chongqing, China (30.7 ng L $\left.{ }^{-1}\right)$, but higher than the values reported from mountain or high-elevation sites in China

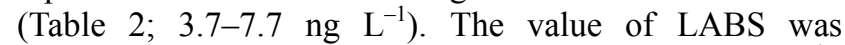
approximately 2.4 times the values of Mt. Leigong $\left(4.0 \mathrm{ng} \mathrm{L}^{-1}\right)$, Mt. Damei (3.7 $\left.\mathrm{ng} \mathrm{L}^{-1}\right)$, and Mt. Ailao (3.7 $\left.\mathrm{ng} \mathrm{L}^{-1}\right)$, and was about 1.3 times the values of Mt. Changbai $\left(7.4 \mathrm{ng} \mathrm{L}^{-1}\right)$ and Mt. Waliguan $\left(6.9 \mathrm{ng} \mathrm{L}^{-1}\right)$. It should be noted that this comparison may be affected by the mismatch in monitoring time and duration. Difference in rain depths among regions is often considered as an important factor to influence the rainwater $\mathrm{Hg}$ concentration because of the below-cloud scavenging and dilution effects (Prestbo and Gay, 2009). However, in spite of the fact that annual rainfall at LABS (3421 mm) was significantly greater than that of the mountain sites in China (290-1931 mm), the VWM Hg concentration at LABS was still higher than those of the Chinese mountain sites (Table 2). These results, therefore, suggested that other factors, such as meteorological conditions, rainfall types, atmospheric chemistry, and $\mathrm{Hg}$ emissions and transport (Prestbo and Gay, 2009; Shah et al., 2016; Mao et al., 2017a, b; Shah and Jaeglé 2017; Sprovieri et al., 2017) could also contribute to the difference in rainwater $\mathrm{Hg}$ concentrations between the LABS and the Chinese mountain sites. In summary, these comparisons indicated that the LABS rainwater $\mathrm{Hg}$ levels were higher than those of the mountain sites in China, but were lower than those of urban sites.

\section{Wet Hg Deposition Fluxes}

Weekly wet $\mathrm{Hg}$ deposition fluxes ranged from 0.01 to $7.6 \mu \mathrm{g} \mathrm{m}^{-2}$ in $2010-2013$, with a mean weekly wet deposition flux of $0.82 \mu \mathrm{g} \mathrm{m}^{-2}$ week $^{-1}$. The greatest rainfall event occurred during 06/05/2012-06/26/2012 with a cumulative rainfall up to $812 \mathrm{~mm}$ (639 $\mathrm{mm}$ during $06 / 05-06 / 12)$. This event was caused by the combination of the southwest monsoon, Meiyu rainfall, and typhoon TALIM (06/1906/21). Rainwater $\mathrm{Hg}$ concentration of this event was $9.4 \mathrm{ng} \mathrm{L}^{-1}$, comparable to the overall VWM Hg concentration (9.2 $\mathrm{ng} \mathrm{L^{-1 }}$ ) in 2010-2013. This event alone contributed about $16 \%\left(7.6 \mu \mathrm{g} \mathrm{m}^{-2}\right)$ of the total wet $\mathrm{Hg}$ deposition flux in $2012\left(48.9 \mu \mathrm{g} \mathrm{m}^{-2}\right)$. More than $27 \%$ of the weekly wet fluxes were greater than $0.82 \mu \mathrm{g} \mathrm{m}^{-2}$ week $^{-1}$, the mean weekly wet flux, and mainly occurred from May to August. All of these high wet flux samples were associated with rainfall greater than $45 \mathrm{~mm}$. The strong fluctuation pattern in the weekly $\mathrm{Hg}$ deposition fluxes at LABS is similar to those MDN sites in the U.S. and some sampling sites in Mexico, where thunderstorms and hurricanes can bring a large amount of rainwater to samples in a short period (Prestbo and Gay, 2009; Hansen and Gay, 2013).

A significant positive correlation between the weekly rainfall and wet $\mathrm{Hg}$ deposition flux was observed (Fig. 3(A); $\left.\mathrm{R}^{2}=0.67, p<0.01\right)$, indicating that wet $\mathrm{Hg}$ flux increased with increasing rainfall at the LABS. About $67 \%$ of the variation in wet $\mathrm{Hg}$ deposition flux could be explained by the variation in rainfall. This result agreed well with those reported from sites in China, Japan, and Taiwan (Sakata and Marumoto, 2005; Sheu and Lin, 2013; Fu et al., 2016), where rainfall explained about $70 \%$ of the wet $\mathrm{Hg}$ flux in various sites across Japan (Sakata and Marumoto, 2005) and more than $80 \%$ at four mountain sites in China (Fu et al., 2016). On the other hand, the correlation between sample $\mathrm{Hg}$ concentration and wet $\mathrm{Hg}$ deposition flux was weak, with a $\mathrm{R}^{2}$ value of 0.032 (Fig. 3(B); $p=0.033$ ).

Annual wet $\mathrm{Hg}$ deposition fluxes at LABS ranged from 24.4 to $48.9 \mu \mathrm{g} \mathrm{m}^{-2}$ (Table 1) with a four-year average of $32.3 \mu \mathrm{g} \mathrm{m}^{-2}$ (Table 2). Wet $\mathrm{Hg}$ flux at LABS was greater than those observed at the remote and rural sites in China, Italy, Tibetan Plateau, Brazil, and Mexico, mainly due to higher rainfall (Table 2). The wet $\mathrm{Hg}$ deposition flux at 

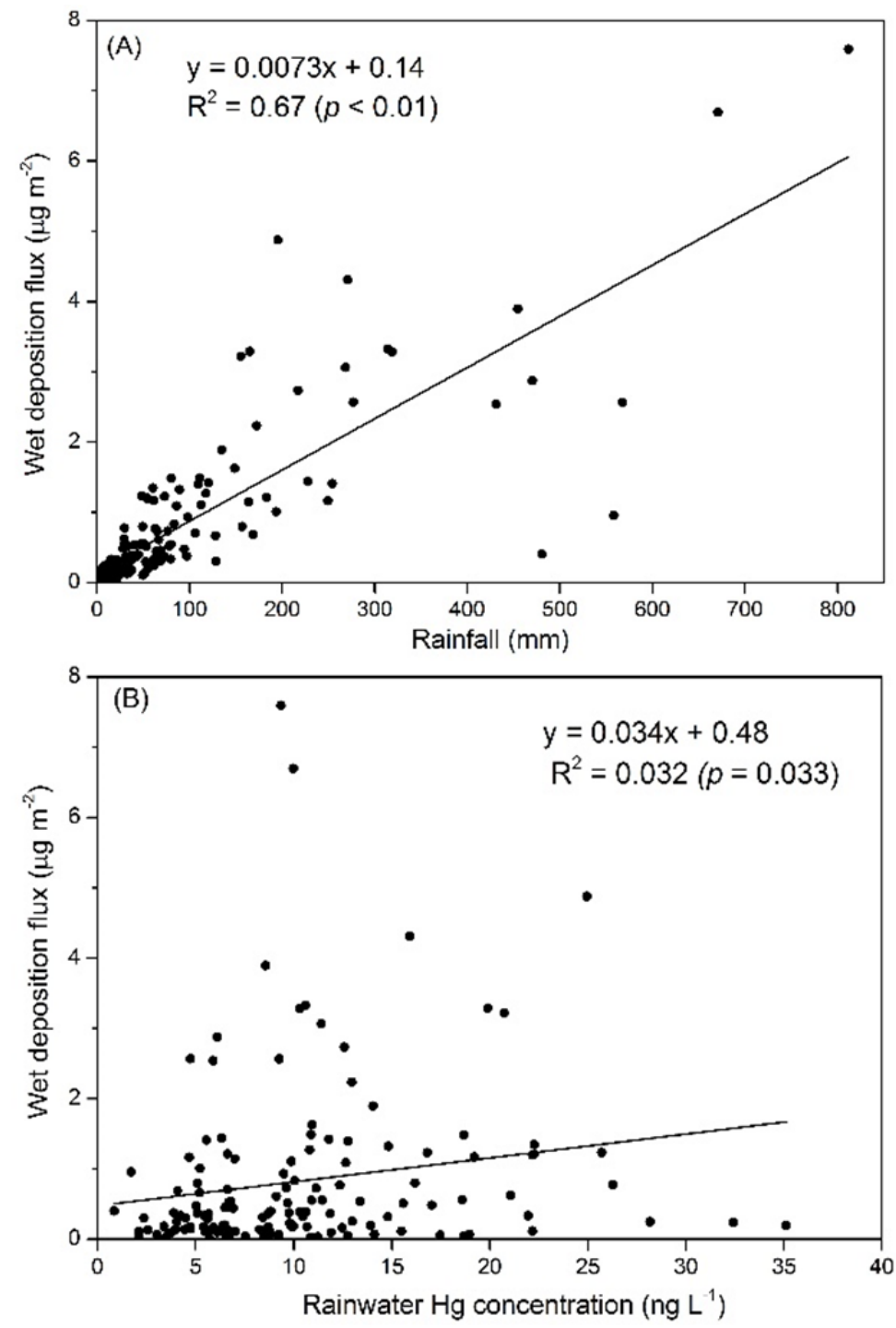

Fig. 3. Relationships between weekly wet $\mathrm{Hg}$ deposition flux and (A) rainfall (B) rainwater $\mathrm{Hg}$ concentration.

Table 1. Summary of rain depths, rainwater $\mathrm{Hg}$ concentrations, and wet $\mathrm{Hg}$ deposition fluxes at LABS between 2010 and 2013.

\begin{tabular}{llllll}
\hline Year & Sample size & $\begin{array}{l}\text { Rain depth } \\
(\mathrm{mm})\end{array}$ & $\begin{array}{l}\text { Sample Hg conc. Range } \\
\left(\mathrm{ng} \mathrm{L}^{-1}\right)\end{array}$ & $\begin{array}{l}\text { VWM Hg conc. } \\
\left(\mathrm{ng} \mathrm{L}^{-1}\right)\end{array}$ & $\begin{array}{l}\text { Wet deposition flux } \\
\left(\mu \mathrm{g} \mathrm{m}^{-2} \mathrm{yr}^{-1}\right)\end{array}$ \\
\hline 2010 & 36 & 3173 & $4.1-24.9$ & 9.6 & 30.5 \\
2011 & 40 & 3271 & $2.1-28.2$ & 7.7 & 25.2 \\
2012 & 36 & 3736 & $2.4-35.1$ & 13.1 & 48.9 \\
2013 & 38 & 3503 & $0.8-32.4$ & 7.0 & 24.4 \\
\hline
\end{tabular}

LABS was about 1.5-6.0 times the values measured at 15 sites in the eastern U.S. (Zhang et al., 2016a). Compared to tropical sites, the mean annual wet $\mathrm{Hg}$ deposition at LABS was about 1.7 times the values reported from Amapá state and Near Manaus, the low-elevation rural sites in northern Brazil. On the other hand, the wet $\mathrm{Hg}$ deposition flux at LABS was close to the value $\left(27.9 \mu \mathrm{g} \mathrm{m}^{-2} \mathrm{yr}^{-1}\right)$ observed at a tropical site in the Luquillo Mountains, Puerto Rico (Shanley et al., 2015), likely due to comparable amounts of rainfall (Table 2). These comparisons indicated that rainfall amount was an important factor driving the wet $\mathrm{Hg}$ deposition flux in the tropical region. For sites of Taiwan, the wet $\mathrm{Hg}$ deposition flux at LABS $\left(32.3 \mu \mathrm{g} \mathrm{m}^{-2}\right)$ was 3 times the value measured at the island of Pengjiayu $\left(10.2 \mu \mathrm{g} \mathrm{m}^{-2}\right.$ ) because of the higher rainfall at LABS (3421 mm) as compared to at Pengjiayu (1438 mm), even though VWM Hg concentrations at both sites were close. LABS is a high-elevation mountain site, while Penjiayu is a low-elevation remote island site (Sheu and Lin, 2013), this comparison likely indicated the influence of geographical 
Table 2. Summary of wet Hg deposition at various sites worldwide.

\begin{tabular}{|c|c|c|c|c|c|}
\hline Location & $\begin{array}{l}\text { Site } \\
\text { characteristic }\end{array}$ & $\begin{array}{l}\text { Rain depth } \\
(\mathrm{mm})\end{array}$ & $\begin{array}{l}\text { VWM } \\
\text { conc. } \\
\text { (ng L }{ }^{-1} \text { ) }\end{array}$ & $\begin{array}{l}\text { Wet deposition } \\
\text { flux } \\
\left(\mu \mathrm{g} \mathrm{m}^{-2} \mathrm{yr}^{-1}\right)\end{array}$ & Reference \\
\hline Mt. Lulin, Taiwan & Mountain & 3421 & 9.2 & 32.3 & This study \\
\hline Pengjiayu, Taiwan & Island & 1438 & 8.9 & 10.2 & Sheu and Lin, 2013 \\
\hline Mt. Waliguan, China & Mountain & 290 & 6.9 & 2.0 & Fu et al., 2016 \\
\hline Mt. Leigong, China & Mountain & 1533 & 4.0 & 6.1 & Fu et al., 2016 \\
\hline Mt. Ailao, China & Mountain & 1931 & 3.7 & 7.2 & Fu et al., 2016 \\
\hline Mt. Damei, China & Mountain & 1621 & 3.7 & 6.0 & Fu et al., 2016 \\
\hline Mt. Changbai, China & Mountain & 751 & 7.4 & 5.6 & Fu et al., 2016 \\
\hline Bayinbuluk, China & High elevation & 266 & 7.7 & 2.0 & Fu et al., 2016 \\
\hline $\begin{array}{l}\text { Southeast Tibet Station, Tibetan } \\
\text { Plateau }\end{array}$ & High elevation & 978 & 4.0 & 3.9 & Huang et al., 2015 \\
\hline Longobucco, Italy & High elevation & 473 & 6.6 & 3.1 & Sprovieri et al., 2017 \\
\hline Puerto Rico, U.S. & Rural & 2855 & 9.8 & 27.9 & Shanley et al., 2015 \\
\hline Cape Point, South Africa & Rural & $134-310$ & $1.8-19.6$ & $0.3-5.2$ & Sprovieri et al., 2017 \\
\hline Hidalgo, Mexico & Rural & 1042 & 8.2 & 9.4 & Hansen and Gay, 2013 \\
\hline Amapá state, Brazil & Rural & 1990 & 9.1 & 18.2 & Fostier et al., 2000 \\
\hline Near Manaus, Brazil & Rural & 2068 & 9.8 & 20.3 & Fadini and Jardim, 2001 \\
\hline Guiyang, China & Urban & 1057 & 11.9 & 12.6 & Fu et al., 2016 \\
\hline Kathmandu, Nepal & Urban & 1914 & 18.3 & 34.9 & Tripathee et al., 2019 \\
\hline Seoul, Korea & Urban & $1235-1645$ & $10.1-16.3$ & $16.8-20.2$ & Seo et al., 2012 \\
\hline Chongqing, China & Urban & 921 & 30.7 & - & Wang et al., 2012 \\
\hline Lhasa, Tibetan Plateau & Urban & 359 & 24.8 & 8.2 & Huang et al., 2013 \\
\hline 10 sites around Japan & Various & $882-2317$ & - & $5.8-17.7$ & $\begin{array}{l}\text { Sakata and Marumoto, } \\
2005\end{array}$ \\
\hline Europe & Various & - & $11.9-18.0$ & $7.0-36.0$ & Fu et al., 2015 \\
\hline 15 sites in North America & Various & - & - & $5.4-21.0$ & Zhang et al., 2016a \\
\hline 10 sites in North America & Various & $360-1470$ & - & $6.0-12.6$ & Zhang et al., 2012 \\
\hline MDN sites across North America & Various & - & 9.5 & $3.0-25.0$ & Prestbo and Gay, 2009 \\
\hline
\end{tabular}

characteristics on wet Hg deposition through its impact on rainfall distribution. Mountains occupy about half the area of Taiwan and usually with high annual rainfall, implying that Taiwan could receive a large amount of wet $\mathrm{Hg}$ deposition every year.

The wet $\mathrm{Hg}$ deposition flux at LABS was higher (4-16 times) than those reported from high-elevation and mountain sites in China, such as Mt. Waliguan, Mt. Leigong, Mt. Ailao, Mt. Damei, and Mt. Changbai (Table 2). Both rainfall amount and rainwater $\mathrm{Hg}$ concentration contributed to this difference (Table 2). Our result suggests a geographical trend with higher wet $\mathrm{Hg}$ deposition to the tropical mountain site (LABS) as compared to sites in the temperate regions, and in inland mountain and high-elevation areas as well. In addition to measurement data, a recent model study was conducted by Horowitz et al. (2017) to estimate the global wet $\mathrm{Hg}$ deposition fluxes using the updated GEOS-Chem model. Annual wet $\mathrm{Hg}$ deposition fluxes of $10-12 \mu \mathrm{g} \mathrm{m}^{-2}$ were estimated for the regions around Taiwan (Horowitz et al., 2017). These values were close to the observed value at Pengjiayu $\left(10.2 \mu \mathrm{g} \mathrm{m}^{-2} \mathrm{yr}^{-1}\right)$. However, the high value at LABS $\left(32.3 \mu \mathrm{g} \mathrm{m}^{-2} \mathrm{yr}^{-1}\right)$ was not captured by this model. Results of the current research tend to support the hypothesis that tropical region, especially the windward maritime slopes, may be hot spots of wet $\mathrm{Hg}$ deposition (Shanley et al., 2015; Horowitz et al., 2017).

\section{Temporal Patterns of Wet Hg Deposition}

The interannual variations in VWM Hg concentration and wet deposition flux at LABS are summarized in Table 1. The VWM Hg concentrations showed a significant interannual variability with the highest value in $2012\left(13.1 \mathrm{ng} \mathrm{L}^{-1}\right)$ and the lowest value obtained in $2013\left(7.0 \mathrm{ng} \mathrm{L}^{-1}\right)$. Interannual variability was also observed for wet $\mathrm{Hg}$ deposition fluxes, with the highest and lowest wet fluxes observed in 2012 $\left(48.9 \mu \mathrm{g} \mathrm{m}^{-2} \mathrm{yr}^{-1}\right)$ and $2013\left(24.4 \mu \mathrm{g} \mathrm{m}^{-2} \mathrm{yr}^{-1}\right)$, respectively. The highest annual rainfall amount $(3736 \mathrm{~mm})$ and VWM $\mathrm{Hg}$ concentration $\left(13.1 \mathrm{ng} \mathrm{L}^{-1}\right)$ in 2012 , resulting in the highest wet $\mathrm{Hg}$ deposition flux in 2012 as compared to other years (Table 1).

Seasonal variations in rainfall amounts, VWM $\mathrm{Hg}$ concentrations, and wet $\mathrm{Hg}$ deposition fluxes were observed at LABS (Fig. 4). Seasonal cumulated rainfalls (four-year mean) were 831, 1703, 601, and $286 \mathrm{~mm}$, whereas seasonal VWM Hg concentrations were 9.4, 9.7, 9.7, and $7.4 \mathrm{ng} \mathrm{L}^{-1}$ in spring (March-May), summer (June-August), fall (September-November), and winter (December-February), respectively (Figs. 4(A)-4(C)). The combination of higher rainfall and rainwater $\mathrm{Hg}$ concentration resulted in the highest wet deposition flux in summer $\left(16.6 \mu \mathrm{g} \mathrm{m}^{-2}\right)$, as compared to winter $\left(1.9 \mu \mathrm{g} \mathrm{m}^{-2}\right)$, fall $\left(4.9 \mu \mathrm{g} \mathrm{m}^{-2}\right)$, and spring $\left(7.9 \mu \mathrm{g} \mathrm{m}^{-2}\right)$. On average, summer contributed about $53 \%$ of the annual wet $\mathrm{Hg}$ deposition flux. The seasonal wet 


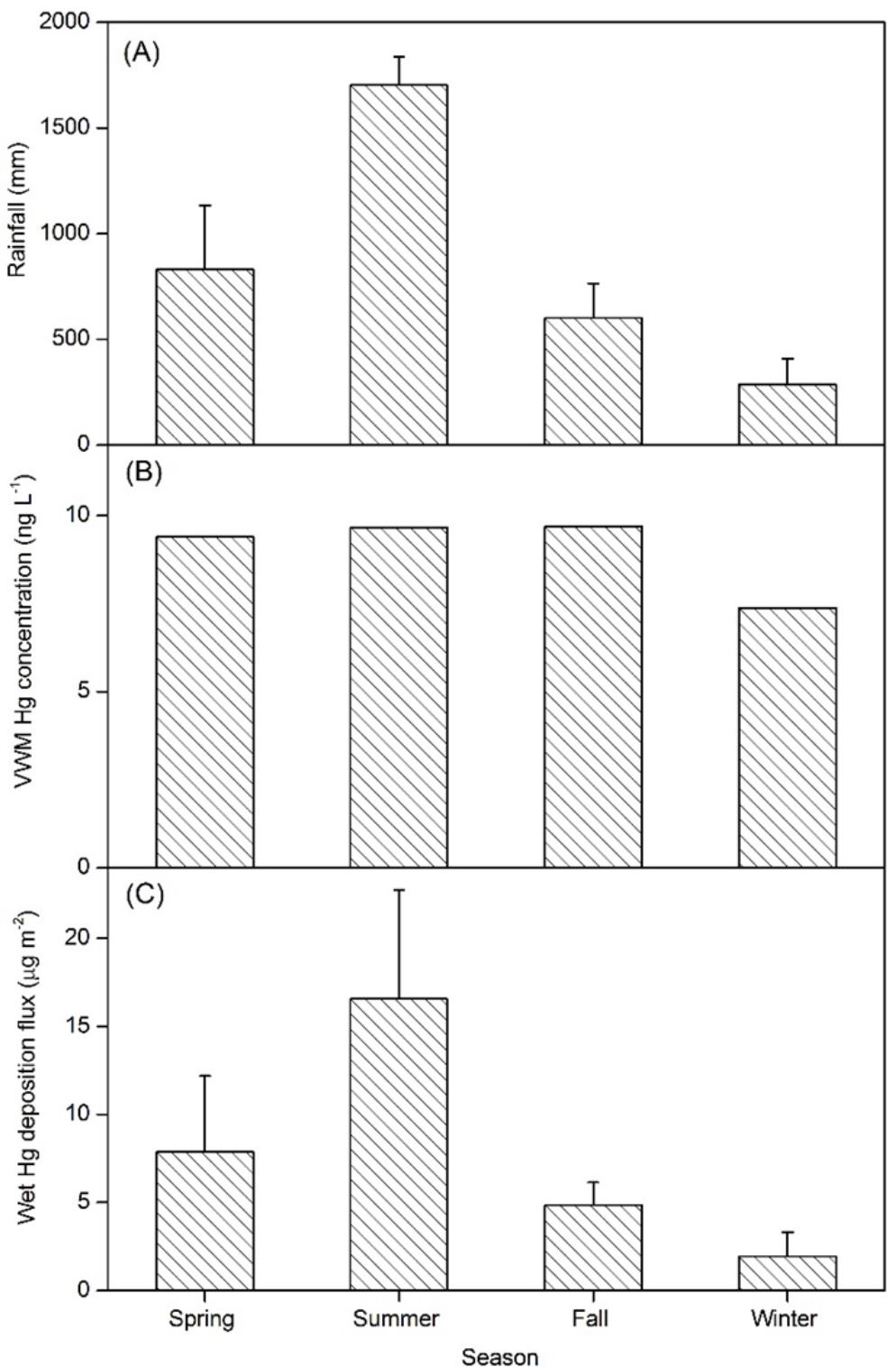

Fig. 4. Seasonal distribution of (A) rainfall, (B) VWM Hg concentration, and (C) wet $\mathrm{Hg}$ deposition flux.

flux pattern at LABS was similar to those observed at 10 sites in Japan (Sakata and Marumoto, 2005), the NADP/MDN sites in the U.S. and Canada (Prestbo and Gay, 2009), Pengjiayu, Taiwan (Sheu and Lin, 2013), Huntington Wildlife Forest, US (Mao et al., 2017b), and two tropical sites at Sisal, Mexico and Puerto Rico (Shanley et al., 2015; Sprovieri et al., 2017). At most of these sites, greater wet $\mathrm{Hg}$ deposition flux in summer was a result of both greater rainwater $\mathrm{Hg}$ concentration and higher rainfall, as was observed at LABS.

Between 2010 and 2013, the lowest VWM Hg concentration was found in winter $(p<0.05)$, whereas the values were nearly equal for spring, summer, and fall (Fig. 4(B)), as shown by the analysis of covariance (ANCOVA) using rainfall as a covariate. This seasonal pattern was different from the pattern, higher $\mathrm{Hg}$ concentrations in winter and lower in summer, reported by $\mathrm{Fu}$ et al. (2016) for some sites in China. Discrepancies between LABS and those Chinese sites could be due to the impact of local anthropogenic $\mathrm{Hg}$ emissions. At these Chinese sites, seasonal patterns of VWM Hg concentration were partially driven by the elevated particulate-bound mercury (PBM) concentrations from local anthropogenic $\mathrm{Hg}$ emissions in winter, and the dilution effect of higher rainfall in summer (Fu et al., 2016). However, there are no local anthropogenic $\mathrm{Hg}$ emission sources near the LABS (Sheu et al., 2010). On the other hand, the pattern of lowest VWM $\mathrm{Hg}$ concentration in winter and higher in other seasons has been observed at Puerto Rico and Pengjiayu, where sites were not affected by direct anthropogenic $\mathrm{Hg}$ emissions. This has been attributed to the effect of rainfall associated with deep convection such as thunderstorm (Sheu and Lin, 2013; Shanley et al., 2015). Higher summer rainwater $\mathrm{Hg}$ concentrations have been observed at many of the NADP/MDN sites that were also attributed to the effect of deep convection (Prestbo and Gay, 2009). Recent observation and model studies demonstrated that deep 
convective rainfall can scavenge $\mathrm{Hg}$ (II) from the upper free troposphere, resulting in elevated rainwater $\mathrm{Hg}$ (Nair et al., 2013; Holmes et al., 2016). Results of these studies thus suggested the importance of rainfall types to the seasonal pattern of rainwater $\mathrm{Hg}$ concentration.

The oxidized forms of $\mathrm{Hg}$, including gaseous oxidized mercury (GOM) and PBM, comprise the majority of rainwater $\mathrm{Hg}$ concentration due to its higher solubility (Manson and Sheu, 2002; Driscoll et al., 2013). Anthropogenic $\mathrm{Hg}$ (II) emissions and photochemical oxidation of GEM, are the primary sources of $\mathrm{Hg}$ (II) in the atmosphere (Weiss-Penzias et al., 2011; Weiss-Penzias et al., 2016; Shah and Jaeglé, 2017). Transport of air pollutants, including $\mathrm{Hg}$, from East and Southeast Asia to Taiwan has been well documented by numerous studies (e.g., Sheu et al., 2010; Sheu and Lin, 2011; Sheu et al., 2013; Ou-Yang et al., 2014; Pani et al., 2016; Pani et al., 2017; Nguyen et al., 2019; Sheu et al., 2019). Export of atmospheric $\mathrm{Hg}$ from East and Southeast Asia to LABS occurs mainly in fall, winter, and spring due to the prevailing westerlies wind and northeast monsoon (Sheu et al., 2010; Nguyen et al., 2019). Seasonal distribution of BWTs in 2010-2013 (Figs. 5(A)-5(D)) indicated that air masses reached LABS mainly came from South China Sea and the West Pacific Ocean in summer, whereas air masses were mainly from the East Asia continent and Indochina Peninsula in fall, winter, and spring (Figs. 5(A)-5(D)). Although the $\mathrm{Hg}$ emissions from East and Southeast Asia primarily affected LABS in spring, fall, and winter, however, the rainwater VWM Hg concentration was the lowest in winter (Fig. 4(B)).
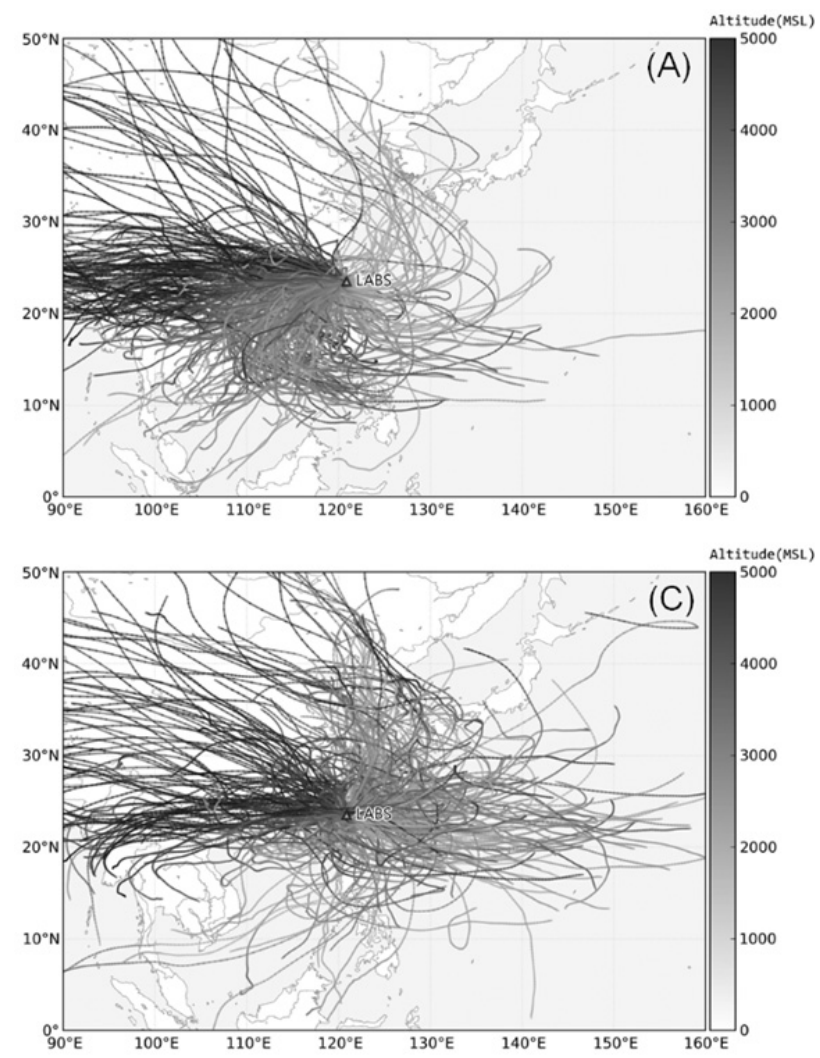

GOM and PBM are the two major contributors to the $\mathrm{Hg}$ in rainwater. However, these $\mathrm{Hg}$ forms have short lifetimes and hence tend to deposit near the emission sources instead of being transported long-distance (Driscoll et al., 2013). A recent model study indicated a negative transport budget of GOM/PBM in mainland China, suggesting the direct GOM/PBM emissions deposit domestically rather than being exported to downwind regions (Wang et al., 2018). Therefore, the contribution of direct anthropogenic GOM/PBM emitted from East and Southeast Asia to the wet $\mathrm{Hg}$ deposition at LABS might be limited. However, the anthropogenic GEM emitted from East and Southeast Asia can be transported to upper troposphere where it could be oxidized to produce $\mathrm{Hg}(\mathrm{II})$ then scavenged by cloud water and rainwater and hence contribute to the wet $\mathrm{Hg}$ deposition (Strode et al., 2008; Sheu and Lin, 2013).

In summary, the seasonal pattern of VWM $\mathrm{Hg}$ concentration at LABS cannot be fully explained by the seasonal export pattern of air pollutants from East and Southeast Asia. This suggests that processes other than the export of Asian atmospheric $\mathrm{Hg}$ are also influencing rainwater $\mathrm{Hg}$ concentrations. As mentioned previously, rainfall type could be an important factor in determining the $\mathrm{Hg}$ concentration in rainwater (Holmes et al., 2016). LABS is located in a region with pronounced seasonal monsoon activities, hence rainfall types vary seasonally (Lin et al., 1999; Sheu et al., 2010; Lin et al., 2013). Therefore, the seasonal differences in rainwater $\mathrm{Hg}$ concentrations could be related to the seasonal differences in rainfall types, which are explored in the following section.
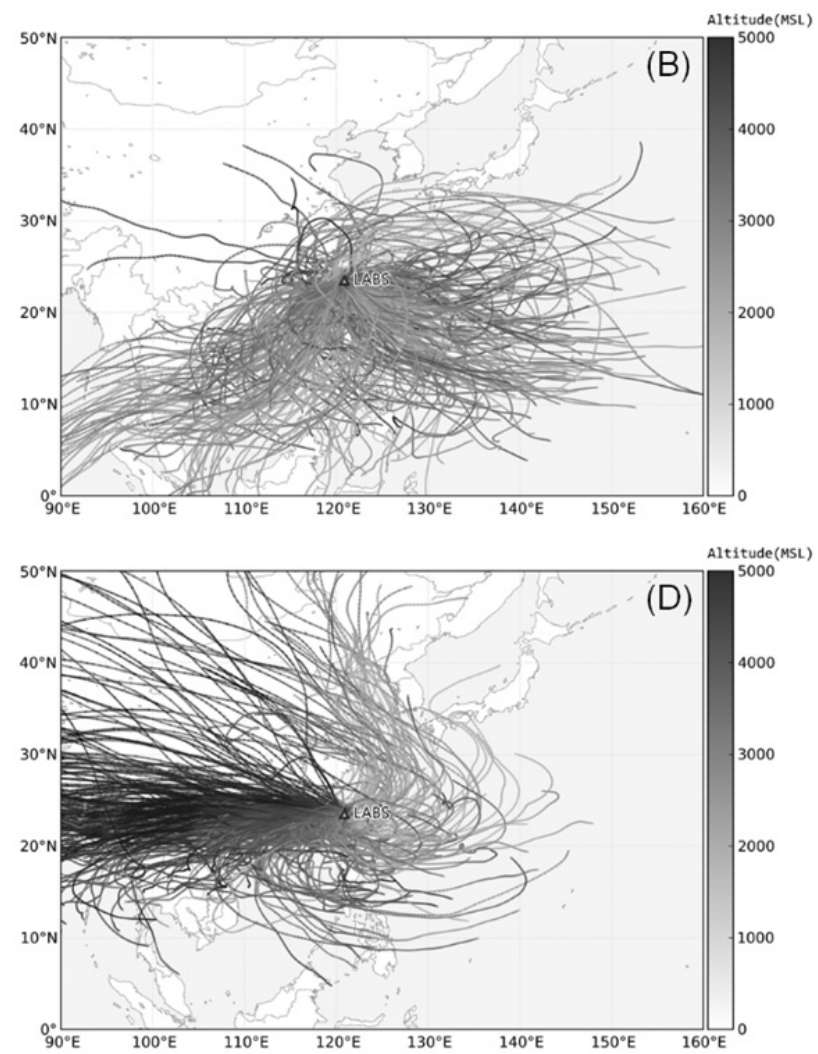

Fig. 5. Five-day backward trajectories of (A) spring, (B) summer, (C) fall, and (D) winter in 2010-2013. 


\section{Influence of Rainfall Types on Rainwater $\mathrm{Hg}$ Concentration}

Effects of rainfall type on wet $\mathrm{Hg}$ deposition, including rainwater $\mathrm{Hg}$ concentration and wet flux, over various sampling sites in the U.S. have been discussed by recent publications (Holmes et al., 2016; Kaulfus et al., 2017). The current study focuses on exploring the influence of rainfall type on the concentration and seasonal pattern of rainwater $\mathrm{Hg}$. To elucidate the impact of rainfall type on rainwater $\mathrm{Hg}$ concentration at LABS, seven rainfall types were categorized based on the approach proposed by Lin et al. (1999), including northeast flow (NE), frontal system in fall and winter (FA), circulation associated with high pressure in spring (HS), frontal system in spring (FS), low pressure in southern China or the South China Sea (LS), Pacific high pressure (PH), and outskirts of typhoon circulation (TP).

The VWM Hg concentration associated with each rainfall type was shown in Fig. 6. VWM Hg concentrations decreased in the following order: $\mathrm{PH}\left(13.5 \mathrm{ng} \mathrm{L^{-1 }}\right)>\mathrm{HS}$ $\left(11.2 \mathrm{ng} \mathrm{L}^{-1}\right)>\mathrm{FA}\left(10.7 \mathrm{ng} \mathrm{L}^{-1}\right)>\operatorname{LS}\left(8.7 \mathrm{ng} \mathrm{L}^{-1}\right) \approx \mathrm{FS}$ $\left(8.7 \mathrm{ng} \mathrm{L}^{-1}\right)>\mathrm{TP}\left(8.6 \mathrm{ng} \mathrm{L}^{-1}\right)>\mathrm{NE}\left(7.3 \mathrm{ng} \mathrm{L}^{-1}\right)$. Rain events associated with the $\mathrm{PH}$ weather system were about $2.3-$ $6.2 \mathrm{ng} \mathrm{L}^{-1}$ greater in VWM Hg concentration as compared to other rainfall types. $\mathrm{PH}$ weather system often occurs in summer months in Taiwan. Because of intense surface heating under summer $\mathrm{PH}$ conditions, precipitation usually occurs locally due to strong convection, resulting in afternoon shower or thunderstorm (Lin et al., 1999; Cheng et al., 2014). Holmes et al. (2016) analyzed 800 individual rainfall events to investigate the contribution of thunderstorms (deep convection) to rainwater $\mathrm{Hg}$ concentration over various sites in the eastern U.S. during 2006-2011. They found that thunderstorms increased $\mathrm{Hg}$ concentration by $50 \%$ relative to other weak convective rainfall types. This value is close to our finding at LABS (47\%), suggesting the important role of strong convection in driving rainwater $\mathrm{Hg}$ concentration at LABS. This enhancement in rainwater $\mathrm{Hg}$ has been attributed to the scavenging of upper-altitude GOM

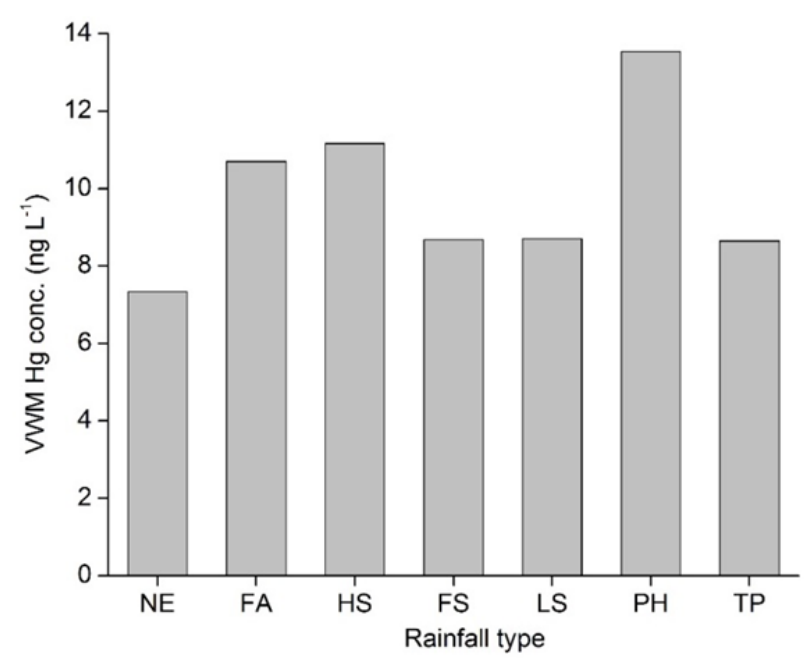

Fig. 6. VWM Hg concentrations associated with various rainfall types in 2010-2013.

by deep convection (Selin and Jacob, 2008). Accordingly, the occurrence frequency of $\mathrm{PH}$ and other rainfall types could influence the seasonal pattern of rainwater $\mathrm{Hg}$ concentrations.

Seasonal relative frequency distribution in rainfall types at LABS between 2010 and 2013 is shown in Fig. 7 and a clear difference was observed. In winter, $77 \%$ of the rain events at LABS were categorized as NE rainfall type, which is the rainfall type with the lowest $\mathrm{Hg}$ concentration, leading to the lowest seasonal VWM Hg concentration. On the other hand, about $1 / 3$ of the rain events in summer were under the categories of $\mathrm{PH}$ (Fig. 7), the rainfall type with highest $\mathrm{Hg}$ concentration (Fig. 6), resulting in the highest seasonal VWM Hg concentration. Therefore, it is evident that the seasonal distribution of rainfall types could influence the seasonal pattern of rainwater $\mathrm{Hg}$ concentrations. It is worth noting that mean rain depth per event was higher in summer $\left(175.6 \mathrm{~mm} \mathrm{event}^{-1}\right)$ than in winter $\left(38.9 \mathrm{~mm} \mathrm{event}^{-1}\right)$. The dilution effect should be more effective in summer

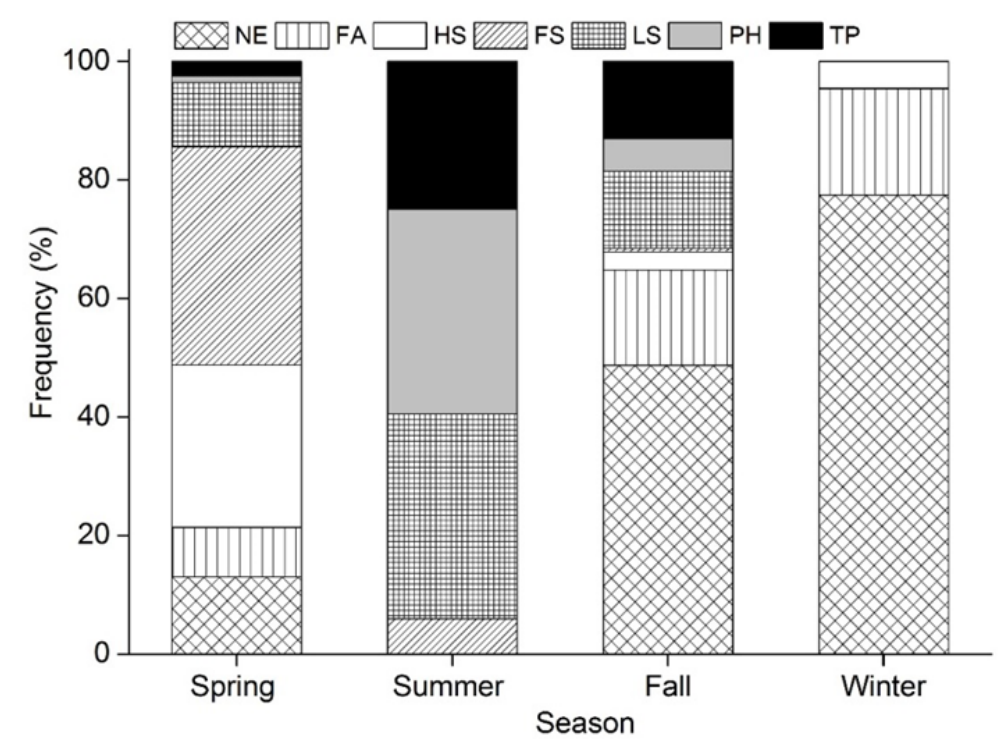

Fig. 7. Seasonal relative distribution frequencies of rainfall types in 2010-2013. 
that would have led to lower rainwater $\mathrm{Hg}$ concentrations. However, because of the continuous supply of upperaltitude GOM to cloud water during PH-type rain events to counteract the dilution effect, rainwater $\mathrm{Hg}$ concentrations remained high in summer.

Elevated GOM concentrations have been observed frequently at mountain and high-elevation sites, such as LABS, Mount Bachelor Observatory and Storm Peak Laboratory, (Swartzendruber et al., 2006; Fain et al., 2009; Sheu et al., 2010). Aircraft measurements and model simulation also suggested the formation of GOM in the upper atmosphere (Sillman et al., 2007; Talbot et al., 2007). Results of these studies thus indicated the existence of a GOM pool in the free troposphere, supporting the argument about the continuous supply of upper-altitude GOM to cloud water in PH-type rain events in summer. Although direct anthropogenic GOM emissions from the East Asian continent may not contribute to the measured rainwater $\mathrm{Hg}$ concentrations, anthropogenic GEM emissions could be transported to the upper troposphere where they can be oxidized to form GOM (Strode et al., 2008), which will then be scavenged by cloud water and rainwater.

\section{CONCLUSIONS}

The purpose of this study was to characterize the wet $\mathrm{Hg}$ deposition to LABS, a tropical mountain site with high rainfall in central Taiwan. In 2010-2013, rainwater $\mathrm{Hg}$ concentrations ranged between 0.8 and $35.1 \mathrm{ng} \mathrm{L}^{-1}$, with an overall VWM Hg concentration of $9.2 \mathrm{ng} \mathrm{L}^{-1}$. A significant but weak correlation $\left(\mathrm{R}^{2}=0.036, p=0.022\right)$ was found between weekly rainwater $\mathrm{Hg}$ concentration and rainfall, suggesting the scavenging of atmospheric oxidized $\mathrm{Hg}$ by rainwater in the early stages of rain events and the dilution effect caused by substantial rainfall. The VWM $\mathrm{Hg}$ concentration at LABS was higher than those reported from Chinese mountain sites, suggesting factors other than scavenging and dilution, such as meteorological conditions, rainfall type, atmospheric chemistry, and $\mathrm{Hg}$ emissions and transport, could also contribute to this difference.

Weekly wet $\mathrm{Hg}$ deposition fluxes ranged between 0.01 and $7.6 \mu \mathrm{g} \mathrm{m}^{-2}$ with a mean value of $0.82 \mu \mathrm{g} \mathrm{m}^{-2}$. A positive correlation $\left(\mathrm{R}^{2}=0.67, p<0.01\right)$ was observed between weekly rainfall and wet deposition flux, whereas a weak correlation $\left(\mathrm{R}^{2}=0.032, p=0.033\right)$ was observed between sample $\mathrm{Hg}$ concentration and wet deposition flux. This indicates that rainfall amount is a more important factor than rainwater $\mathrm{Hg}$ concentration in determining the wet $\mathrm{Hg}$ deposition flux. Annual wet $\mathrm{Hg}$ deposition ranged between 24.4 and $48.9 \mu \mathrm{g} \mathrm{m}^{-2}$ with a mean value of $32.3 \mu \mathrm{g} \mathrm{m}^{-2}$. This mean value was about $1.5-6.0$ times the values reported from 15 sites in the U.S. and 4-16 times the values reported from mountain and high-elevation sites in China. Both rainwater $\mathrm{Hg}$ concentration and rainfall amount contributed to this difference, but rainfall amount played a more important role.

Seasonally, both the rain depth and rainwater VWM Hg concentration were the highest in summer, resulting in the highest wet $\mathrm{Hg}$ deposition flux in summer. On average, summer contributed about $53 \%$ of the annual wet $\mathrm{Hg}$ deposition flux. The seasonal pattern of rainwater $\mathrm{Hg}$ concentration was different from the pattern of the East Asian air pollutant export, indicating other factors were also influencing the seasonal distribution of rainwater $\mathrm{Hg}$ concentrations, such as rainfall type. Seven rainfall types have been categorized and the PH type was found to have the highest VWM Hg concentration as compared to the other rainfall types. In summer, about $1 / 3$ of the rain events were under the categories of $\mathrm{PH}$ and hence resulting in the highest seasonal VWM Hg concentration. Scavenging of free tropospheric GOM by deep convection during $\mathrm{PH}-$ type rain events was likely the cause for the elevated rainwater $\mathrm{Hg}$ levels.

Results of this study indicated that tropical areas in East and Southeast Asia, especially the windward maritime slopes, could be hot spots of wet $\mathrm{Hg}$ deposition. However, measurement data are very limited in this region. Recently, the Asia Pacific Mercury Monitoring Network (APMMN), a network of sites operating in Asia and the Western Pacific region to measure $\mathrm{Hg}$ in precipitation cooperatively, has been established to fill this data gap. Some sampling sites of the APMMN are in the tropical areas of Southeast and South Asia and thus can provide the much needed wet $\mathrm{Hg}$ deposition measurement data. Besides, dry deposition of atmospheric $\mathrm{Hg}$ could also play an important role in total $\mathrm{Hg}$ deposition budget, particularly in East and Southeast Asia where with high $\mathrm{Hg}$ emissions. Therefore, dry $\mathrm{Hg}$ deposition studies are also needed to complement the wet deposition for a better estimation of total deposition.

\section{ACKNOWLEDGMENTS}

We gratefully acknowledge the assistance of staff from the Cloud and Aerosol Lab of National Central University for rainwater collection and instrument maintenance. This study has been financially supported by Taiwan's Ministry of Science and Technology under contracts No. NSC 962745-M-008-011 and NSC 97-2111-M-008-022.

\section{REFERENCES}

Brunke, E., Walters, C., Mkololo, T., Martin, L., Labuschagne, C., Silwana, B., Slemr, F., Weigelt, A., Ebinghaus, R. and Somerset, V. (2016). Mercury in the atmosphere and in rainwater at Cape Point, South Africa. Atmos. Environ. 125: 24-32.

Celâl Şengör, A.M., Chandrasekhar, S., Spencer, J.E., Beaufort, L.F., Gourou P., Yefemov, Y.K., Ryabchikov, A.M., Alexeeva, N.N., Owen, L., Chapman, G.P., Leinbach, T.R., Narasimhan, C.V. and Pannell, C.W. (2019). Climate - Air masses and wind patterns. Asia. https://www.britannica.com/place/Asia/Climate.

Chand, D., Jaffe, D., Prestbo, E., Swartzendruber, P.C., Hafner, W., Weiss-Penzias, P., Kato, S., Takami, A., Hatakeyama, S. and Kajii, Y. (2008). Reactive and particulate mercury in the Asian marine boundary layer. Atmos. Environ. 42: 7988-7996.

Chen, L., Wang, H.H., Liu, J.F., Tong, Y.D., Ou, L.B., 
Zhang, W., Hu, D., Chen, C. and Wang, X.J. (2014). Intercontinental transport and deposition patterns of atmospheric mercury from anthropogenic emissions. Atmos. Chem. Phys. 14: 10163-10176.

Chen, L., Liang, S., Zhang, Y., Liu, M., Meng, J., Zhang, H., Tang, X., Li, Y., Tong, Y., Zhang, W., Wang, X. and Shu, J. (2018). Atmospheric mercury outflow from china and interprovincial trade. Environ. Sci. Technol. 52: $13792-13800$.

Chen, W.K., Li, T.C., Sheu, G.R., Lin, N.H., Chen, L.Y. and Yuan, C.S. (2016). Correlation analysis, transportation mode of atmospheric mercury and criteria air pollutants, with meteorological parameters at two remote sites of mountain and offshore island in Asia. Aerosol Air Qual. Res. 16: 2692-2705.

Cheng, T.C., Yen, M.C., Tsay, J.D., Liao, C.C. and Takle, E.S. (2014). Impact of the afternoon thunderstorm on the land-sea breeze in the Taipei basin during summer: An experiment. J. Appl. Meteor. Climatol. 53: 17141737.

Civerolo, K.L., Rattigan, O.V., Felton, H.D., Hirsch, M.J. and DeSantis, S. (2014). Mercury wet deposition and speciated air concentrations from two urban sites in New York State: Temporal patterns and regional context. Aerosol Air Qual. Res. 14: 1822-1837.

Cole, A.S., Steffen, A., Eckley, C.S., Narayan, J., Pilote, M., Tordon, R., Graydon, J.A., St Louis, V.L., Xu, X.H. and Branfireun, B.A., (2014). A survey of mercury in air and precipitation across Canada: Patterns and trends. Atmosphere 5: 635-668.

Draxler, R.R. and Rolph, G.D. (2013). HYSPLIT (HYbrid Single-Particle Lagrangian Integrated Trajectory) Model Access via NOAA ARL READY. NOAA Air Resources Laboratory, Silver Spring, MD. http://ready.arl.noaa.gov/ HYSPLIT.php.

Driscoll, C.T., Mason, R.P., Chan, H.M., Jacob, D.J. and Pirrone, N. (2013). Mercury as a global pollutant: sources, pathways, and effects. Environ. Sci. Technol. 47: 4967-4983.

Fadini, P.S. and Jardim, W.F. (2001). Is the Negro River Basin (Amazon) impacted by naturally occurring mercury? Sci. Total Environ. 275: 71-82.

Faïn, X., Obrist, D., Hallar, A.G., Mccubbin, I. and Rahn, T. (2009). High levels of reactive gaseous mercury observed at a high elevation research laboratory in the Rocky Mountains. Atmos. Chem. Phys. 9: 8049-8060.

Fostier, A.H., Forti, M.C., Guimaraes, J.R.D., Melfi, A.J., Boulet, R., Espirito Santo, C.M. and Krug, F.J. (2000). Mercury fluxes in a natural forested Amazonian catchment (Serra do Navio, Amapa State, Brazil). Sci. Total Environ. 260: 201-11.

Friedli, H.R., Radke, L.F., Prescott, R., Li, P., Woo, J.H. and Carmichael, G.R. (2004). Mercury in the atmosphere around Japan, Korea, and China as observed during the 2001 ACE-Asia field campaign: Measurements, distributions, sources, and implications. J. Geophys. Res. 109: D19S25.

Fu, X.W., Zhang, H., Yu, B., Wang, X., Lin, C.J. and Feng, $X$. (2015). Observations of atmospheric mercury in
China: A critical review. Atmos. Chem. Phys. 15: $9455-$ 9476.

Fu, X., Yang, X., Lang, X., Zhou, J., Zhang, H., Yu, B., Yan, H., Lin, C.J. and Feng, X. (2016). Atmospheric wet and litterfall mercury deposition at urban and rural sites in China. Atmos. Chem. Phys. 16: 11547-11562.

Gratz, L.E., Keeler, G.J. and Miller, E.K. (2009). Longterm relationships between mercury wet deposition and meteorology. Atmos. Environ. 43: 6218-6229.

Hansen, A. and Gay, D. (2013). Observations of mercury wet deposition in Mexico, Environ. Sci. Pollut. Res. 20: 8316-8325.

Holmes, C.D., Krishnamurthy, N.P., Caffrey, J.M., Landing, W.M., Edgerton, E.S., Knapp, K.R. and Nair, U.S. (2016). Thunderstorms increase mercury wet deposition. Environ. Sci. Technol. 50: 9343-9350.

Horowitz, H.M., Jacob, D.J., Zhang, Y., Dibble, T.S., Slemr, F., Amos, H.M., Schmidt, J.A., Corbitt, E.S., Marais, E.A. and Sunderland, E.M. (2017). A new mechanism for atmospheric mercury redox chemistry: Implications for the global mercury budget. Atmos. Chem. Phys. 17: 6353-6371.

Huang, J., Kang, S., Wang, S., Wang, L., Zhang, Q., Guo, J., Wang, K., Zhang, G. and Tripathee, L. (2013). Wet deposition of mercury at Lhasa, the capital city of Tibet. Sci. Total Environ. 447: 123-132.

Huang, J., Kang, S., Zhang, Q., Guo, J., Sillanpää, M., Wang, Y., Sun, S., Sun, X. and Tripathee, L. (2015). Characterizations of wet mercury deposition on a remote high-elevation site in the southeastern Tibetan Plateau. Environ. Pollut. 206: 518-526.

Jen, Y.H., Chen, W.H., Hung, C.H., Yuan, C.S. and Ie, I.R. (2014). Field measurement of total gaseous mercury and its correlation with meteorological parameters and criteria air pollutants at a coastal site of the Penghu Islands. Aerosol Air Qual. Res. 14: 364-375.

Kaulfus, A.S., Nair, U., Holmes, C.D. and Landing, W.M. (2017). Mercury wet scavenging and deposition differences by precipitation type. Environ. Sci. Technol. 51: 2628-2634.

Keeler, G.J., Gratz, L.E. and Al-Wali, K. (2005). Longterm atmospheric mercury wet deposition at Underhill, Vermont. Ecotoxicology 14: 71-83.

Landis, M.S. and Keeler, G.J. (1997). Critical evaluation of a modified automatic wet-only precipitation collector for mercury and trace element determination. Environ. Sci. Technol. 31: 2610-2615.

Lin, C.J., Pan, L., Streets, D.G., Shetty, S.K., Jang, C., Feng, X., Chu, H.W. and Ho, T.C. (2010). Estimating mercury emission outflow from East Asia using CMAQHg. Atmos. Chem. Phys. 10: 1853-1864.

Lin, N.H., Lee, H.H. and Chang, M.B. (1999). Evaluation of the characteristics of acid precipitation in Taipei, Taiwan using cluster analysis. Water Air Soil Pollut. 113: 241-260.

Lin, N.H., Tsay, S.C., Maring, H.B., Yen, M.C., Sheu, G.R., Wang, S.H., Chi, K.H., Chuang, M.T., Ou-Yang, C.F., Fu, J.S., Reid, J.S., Lee, C.T., Wang, L.C., Wang, J.L., Hsu, C.N., Sayer, A.M., Holben, B.N., Chun, Y.C., 
Anh, N.X., Sopajaree, K., Chen, S.J., Cheng, M.T., Tsuang, B.J., Tsai, C.J., Peng, C.M., Schnell, R.C., Conway, T.J., Chang, C.T., Lin, K.S., Tsai, Y.I., Lee, W.J., Chang, S.C., Liu, J.J. and Chiang, W.L. (2013). An overview of regional experiments on biomass burning aerosols and related pollutants in Southeast Asia: From BASE-ASIA and the Dongsha Experiment to 7-SEAS. Atmos. Environ. 78: 1-19.

Mao, H., Cheng, I. and Zhang, L. (2016). Current understanding of the driving mechanisms for spatiotemporal variations of atmospheric speciated mercury: A review. Atmos. Chem. Phys. 16: 1289712924.

Mao, H., Hall, D., Ye, Z., Zhou, Y., Felton, D. and Zhang, L. (2017a). Impacts of large-scale circulation on urban ambient concentrations of gaseous elemental mercury in New York, USA. . Atmos. Chem. Phys. 17: 1165511671.

Mao, H., Ye, Z. and Driscoll, C. (2017b). Meteorological effects on $\mathrm{Hg}$ wet deposition in a forested site in the Adirondack region of New York during 2000-2015. Atmos. Environ. 168: 90-100.

Mason, R.P. (2013). Trace metals in aquatic systems. Wiley Blackwell, Hoboken, N.J., 440 pp.

Mason, R.P. and Sheu, G.R. (2002). Role of the ocean in the global mercury cycle. Global Biogeochem. Cycles 16: 1093.

Nair, U.S., Wu, Y., Holmes, C.D., Ter Schure, A., Kallos, G. and Walters, J.T. (2013). Cloud-resolving simulations of mercury scavenging and deposition in thunderstorms. Atmos. Chem. Phys. 13: 10143-10157.

Nguyen, D.L., Kim, J.Y., Shim, S.G., Ghim, Y.S. and Zhang, X.S. (2016). Shipboard and ground measurements of atmospheric particulate mercury and total mercury in precipitation over the Yellow Sea region. Environ. Pollut. 219: 262-274.

Nguyen, L.S.P., Sheu, G.R., Lin, D.W., and Lin, N.H. (2019). Temporal changes in atmospheric mercury concentrations at a background mountain site downwind of the East Asia continent in 2006-2016. Sci. Total Environ. 686: 1049-1056.

Ou-Yang, C.F., Lin, N.H., Lin, C.C., Wang, S.H., Sheu, G.R., Lee, C.T., Schnell, R.C., Lang, P.M., Kawasato, T. and Wang, J.L. (2014). Characteristics of atmospheric carbon monoxide at a high-mountain background station in East Asia. Atmos. Environ. 89: 613-622.

Pani, S.K., Wang, S.H., Lin, N.H., Tsay, S.C., Lolli, S., Chuang, M.T., Lee, C.T., Chantara, S. and Yu, J.Y. (2016). Assessment of aerosol optical property and radiative effect for the layer decoupling cases over the Northern South China Sea during the 7-SEAS/Dongsha Experiment. J. Geophys. Res. Atmos. 121: 4894-4906.

Pani, S.K., Lee, C.T., Chou, C.C.K., Shimada, K., Hatakeyama, S., Takami, A., Wang, S.H. and Lin, N.H. (2017). Chemical characterization of wintertime aerosols over islands and mountains in East Asia: Impacts of the continental Asian outflow. Aerosol Air Qual. Res. 17: 3006-3036.

Prestbo, E.M. and Gay, D.A. (2009). Wet deposition of mercury in the U.S. and Canada, 1996-2005: Results and analysis of the NADP mercury deposition network (MDN). Atmos. Environ. 43: 4223-4233.

Sakata, M. and Marumoto, K. (2005). Wet and dry deposition fluxes of mercury in Japan. Atmos. Environ. 39: 3139-3146.

Selin, N.E. and Jacob, D.J. (2008). Seasonal and spatial patterns of mercury wet deposition in the United States: Constraints on the contribution from North American anthropogenic sources. Atmos. Environ. 42: 5193-5204.

Seo, Y.S., Han, Y.J., Choi, H.D., Holsen, T.M. and Yi, S.M. (2012). Characteristics of total mercury (TM) wet deposition: Scavenging of atmospheric mercury species. Atmos. Environ. 49: 69-76.

Shah, V., Jaeglé, L., Gratz, L.E., Ambrose, J.L., Jaffe, D.A., Selin, N.E., Song, S., Campos, T.L., Flocke, F.M., Reeves, M., Stechman, D., Stell, M., Festa, J., Stutz, J., Weinheimer, A.J., Knapp, D.J., Montzka, D.D., Tyndall, G.S., Apel, E.C., Hornbrook, R.S., Hills, A.J., Riemer, D.D., Blake, N.J., Cantrell, C.A. and Mauldin III, R.L. (2016). Origin of oxidized mercury in the summertime free troposphere over the southeastern US. Atmos. Chem. Phys. 16: 1511-1530.

Shah, V. and Jaeglé, L. (2017). Subtropical subsidence and surface deposition of oxidized mercury produced in the free troposphere. Atmos. Chem. Phys. 17: 8999-9017.

Shanley, J.B., Engle, M.A., Scholl, M., Krabbenhoft, D.P., Brunette, R., Olson, M.L. and Conroy, M.E. (2015). High mercury wet deposition at a "clean air" site in Puerto Rico. Environ. Sci. Technol. 49: 12474-12482.

Sheu, G.R., Lin, N.H., Wang, J.L., Lee, C.T., Ou Yang, C.F. and Wang, S.H. (2010). Temporal distribution and potential sources of atmospheric mercury measured at a high-elevation background station in Taiwan. Atmos. Environ. 44: 2393-2400.

Sheu, G.R. and Lin, N.H. (2011). Mercury in cloud water collected on Mt. Bamboo in northern Taiwan during the northeast monsoon season. Atmos. Environ. 45: 44544462.

Sheu, G.R. and Lin, N.H. (2013). Characterizations of wet mercury deposition to a remote islet (Pengjiayu) in the subtropical Northwest Pacific Ocean. Atmos. Environ. 77: 474-481.

Sheu, G.R., Lin, N.H., Lee, C.T., Wang, J.L., Chuang, M.T., Wang, S.H., Chi, K.H. and OuYang, C.F. (2013). Distribution of atmospheric mercury in northern Southeast Asia and South China Sea during Dongsha Experiment. Atmos. Environ. 78: 174-183.

Sheu, G.R., Nguyen, L.S.P., Truong, M.T. and Lin, D.W. (2019). Characteristics of atmospheric mercury at a suburban site in northern Taiwan and influence of transboundary haze events. Atmos. Environ. 214: 116827.

Sillman, S., Marsik, F.J., Al-Wali, K.I., Keeler, G.J. and Landis, M.S. (2007). Reactive mercury in the troposphere: Model formation and results for Florida, the northeastern US and the Atlantic Ocean. J. Geophys. Res. 112: D23305.

Sprovieri, F., Pirrone, N., Bencardino, M., D’Amore, F., Angot, H., Barbante, C., Brunke, E.-G., Arcega-Cabrera, 
F., Cairns, W., Comero, S., Diéguez, M.D.C., Dommergue, A., Ebinghaus, R., Feng, X.B., Fu, X., Garcia, P.E., Gawlik, B.M., Hageström, U., Hansson, K., Horvat, M., Kotnik, J., Labuschagne, C., Magand, O., Martin, L., Mashyanov, N., Mkololo, T., Munthe, J., Obolkin, V., Ramirez Islas, M., Sena, F., Somerset, V., Spandow, P., Vardè, M., Walters, C., Wängberg, I., Weigelt, A., Yang, X. and Zhang, H. (2017). Five-year records of mercury wet deposition flux at GMOS sites in the Northern and Southern hemispheres. Atmos. Chem. Phys. 17: 26892708.

Strode, S.A., Jaeglé, L., Jaffe, D.A., Swartzendruber, P.C., Selin, N.E., Holmes, C. and Yantosca, R.M. (2008). Trans-Pacific transport of mercury. J. Geophys. Res. 113: D15305.

Sunderland, E.M. (2007). Mercury exposure from domestic and imported estuarine and marine fish in the U.S. seafood market. Environ. Health Perspect. 115: 235242.

Swartzendruber, P.C., Jaffe, D.A., Prestbo, E.M., WeissPenzias, P., Selin, N.E., Park, R., Jacob, D.J., Strode, S. and Jaeglé, L. (2006). Observations of reactive gaseous mercury in the free troposphere at the Mount Bachelor Observatory. J. Geophys. Res. 111: D24301.

Talbot, R., Mao, H., Scheuer, E., Dibb, J. and Avery, M. (2007). Total depletion of $\mathrm{Hg} 0$ in the upper tropospherelower stratosphere. Geophys. Res. Lett. 34: L23804.

Tripathee, L., Guo, J., Kang, S., Paudyal, R., Huang, J., Sharma, C.M., Zhang, Q., Chen, P., Ghimire, P.S. and Sigdel, M. (2019). Spatial and temporal distribution of total mercury in atmospheric wet precipitation at four sites from the Nepal-Himalayas. Sci. Total Environ. 655: $1207-1217$.

U.S. EPA (2002). Revision E, Mercury in water by Oxidation, Purge and Trap, and Cold Vapor atomic Fluorescence Spectrometry, Tech. Rep., United States Environmental Protection Agency, Washington.

UN Environment. (2019). Global Mercury Assessment 2018. UN Environment Programme, Chemicals and Health Branch Geneva, Switzerland.

UNEP (2013). UNEP: Global Mercury Assessment 2013: sources, Emissions, Releases and Environmental Transport. UNEP Chemicals Branch, Geneva, Switzerland.

Wang, X., Lin, C.J., Feng, X., Yuan, W., Fu, X., Zhang, H., $\mathrm{Wu}, \mathrm{Q}$. and Wang, S. (2018). Assessment of regional mercury deposition and emission outflow in Mainland China. J. Geophys. Res. 123: 9868-9890.
Wang, Y.M., Wang, D.Y., Meng, B., Peng, Y.L., Zhao, L. and Zhu, J.S. (2012). Spatial and temporal distributions of total and methyl mercury in precipitation in core urban areas, Chongqing, China. Atmos. Chem. Phys. 12: 9417-9426.

Weiss-Penzias, P.S., Gustin, M.S. and Lyman, S.N. (2011). Sources of gaseous oxidized mercury and mercury dry deposition at two southeastern U.S. sites. Atmos. Environ. 45: 4569-4579.

Weiss-Penzias, P.S., Gay, D.A., Brigham, M.E., Parsons, M.T., Gustin, M.S. and Schure, A.T. (2016). Trends in mercury wet deposition and mercury air concentrations across the U.S. and Canada. Sci. Total Environ. 568: 546-556.

Wright, L.P., Zhang, L. and Marsik, F.J. (2016). Overview of mercury dry deposition, litterfall, and throughfall studies. Atmos. Chem. Phys. 16: 13399-13416.

Zhang, L., Blanchard, P., Gay, D.A., Prestbo, E.M., Risch, M.R., Johnson, D., Narayan, J., Zsolway, R., Holsen, T.M., Miller, E.K., Castro, M.S., Graydon, J.A., St. Louis, V.L. and Dalziel, J. (2012). Estimation of speciated and total mercury dry deposition at monitoring locations in eastern and central North America. Atmos. Chem. Phys. 12: 4327-4340.

Zhang, L., Wu, Z., Cheng, I., Wright, L.P., Olson, M.L., Gay, D.A., Risch, M.R., Brooks, S., Castro, M.S., Conley, G.D., Edgerton, E.S., Holsen, T.M., Luke, W., Tordon, R. and Weiss-Penzias, P.W. (2016a). The estimated six-year mercury dry deposition across North America. Environ. Sci. Technol. 50: 12864-12873.

Zhang, L., Lyman, S., Mao, H., Lin, C.J., Gay, D.A., Wang, S., Gustin, M.S., Feng, X. and Wania, F. (2017). A synthesis of research needs for improving the understanding of atmospheric mercury cycling. Atmos. Chem. Phys. 17: 9133-9144.

Zhang, Y., Jacob, D.J., Horowitz, H.M., Chen, L., Amos, H.M., Krabbenhoft, D.P., Slemr, F., Louis, V.L.St. and Sunderland, E.M, (2016b). Observed decrease in atmospheric mercury explained by global decline in anthropogenic emissions. Proc. Natl. Acad. Sci. U.S.A. 113: 526-531.

Received for review, May 14, 2019

Revised, August 6, 2019

Accepted, August 12, 2019 